\title{
Chitinolytic bacteria from alkaline hypersaline Mono Lake, California, USA
}

\author{
Gary R. LeCleir, James T. Hollibaugh* \\ Department of Marine Sciences, University of Georgia, Athens, Georgia 30602-3636, USA
}

\begin{abstract}
Chitinolytic activity was detected in sediment and water-column samples from Mono Lake, California, USA, using fluorogenic analogues. In order to learn more about chitin degradation in Mono Lake, we analyzed the phylogenetic composition of bacterial assemblages in chitin-enrichment cultures and associated with Artemia monica exuvia. We also isolated chitinolytic bacteria from aerobic and anaerobic water and sediment samples. We screened these isolates for their ability to hydrolyze chitin analogs, for the formation of clearing zones on chitin plates, and for growth with chitin as the sole carbon and energy source. We characterized the isolates phylogenetically by determining partial sequences of their $16 \mathrm{~S}$ rRNA genes. Three ribotypes, most closely related to Paracoccus sp. MBIC4036 (AB025192), Arhodomonas sp. EL-201 (AJ315984), and Psychroflexus tropicus (AF513434), were only found in Mono Lake exuvium and chitin-enrichment clone libraries. Four ribotypes, retrieved solely from chitin enrichments, were closely related to Proteobacteria. The majority (73\%) of the isolates we obtained were Gram-positive bacteria, and $70 \%$ of the Gram-positive isolates were capable of hydrolyzing at least 1 model substrate.
\end{abstract}

KEY WORDS: DGCE $\cdot$ Chitinolytic bacteria $\cdot$ Mono Lake

Resale or republication not permitted without written consent of the publisher

\section{INTRODUCTION}

Mono Lake is an alkaline, hypersaline lake located east of the Sierra Nevada mountain range in California, USA $\left(38^{\circ} 00^{\prime} \mathrm{N}, 119^{\circ} 02^{\prime} \mathrm{W}\right.$, see bathymetric chart at http://geopubs.wr.usgs.gov/map-mf/mf2393/). The lake has a pH of 9.8 and a salinity of approximately 85 ppt (Humayoun et al. 2003). The food web of Mono Lake is relatively simple, consisting of bacteria, phytoplankton, rotifers, brine flies Ephedra hians and the brine shrimp Artemia monica. A. monica are the dominant macro-zooplankter in the lake and can achieve population densities $>80000 \mathrm{~m}^{-2}$ in the summer months (Conte et al. 1988).

Artemia monica begin to hatch in early spring (Lenz 1984, Dana et al. 1988, 1990), and adults are observed in Mono Lake by mid-May (Dana et al. 1990). As they progress through each of 12 developmental stages, $A$. monica molt their exoskeletons (exuvia) into the water column (Patten et al. 1987). Arthropod exoskeletons are rich in the structural biopolymer chitin. Chitin is a homopolymer of n-acetyl-D-glucosamine (GlcNAc) that is insoluble in water and is resistant to hydrolysis by most enzymes (Poulicek et al. 1998). Chitin is important in Mono Lake because of the high A. monica population densities and their frequent molts. We have observed a layer of $A$. monica exuvia and carcasses that is several $\mathrm{cm}$ thick on the bottom of Mono Lake, following the fall die-off of the A. monica population (authors' pers. obs.).

Bacteria are considered to be the primary mediators of chitin degradation in aquatic environments (Gooday 1990, Poulicek et al. 1998). The first enzymatic step in the chitin-degradation pathway is performed by chitinases. Chitinases belong to Families 18 and 19 of the glycosyl hydrolases. These 2 enzyme families share no similarity at the amino acid level and actually have different mechanisms of hydrolysis (Henrissat 1991). A wide range of organisms, including bacteria, fungi, and arthropods, produce Family 18 chitinases. Plants and a few bacterial strains produce Family 19 chitinases.

Despite measurements of chitinolytic activity in the sediment and water column, all attempts to amplify chitinase genes from Mono Lake using published PCR 
(polymerase chain reaction) primers (Cottrell et al. 2000, Ramaiah et al. 2000, LeCleir et al. 2004) have failed. We hypothesized that the inherently diverse nature of chitinase genes and the unusual environment of Mono Lake resulted in chitinase gene sequences that are too divergent to be amplified with PCR primers based on current database entries. Some evidence supporting the idea of unique chitinases is that Mono Lake chitinolytic activity has a $\mathrm{pH}$ optimum of $>8$, significantly higher than the $\mathrm{pH}$ optima of chitinases from other environments (G. R. LeCleir unpubl. data).

In order to learn more about chitin degradation in Mono Lake, we used an approach that avoids the limitations imposed by chitinase primer specificity to characterize chitin-degrading populations. We analyzed the composition of the mixed microbial assemblage responding to chitin enrichments by using PCR amplification of 16S rRNA genes and denaturing gradient gel electrophoresis (DGGE; Muyzer et al. 1993) or by cloning and sequencing PCR-amplified 16S rRNA genes. We compared the bacterial assemblage from enrichment experiments with the assemblage associated with Artemia monica and Ephedra hians exuvia collected from Mono Lake surface water. We used standard culturing techniques and media selective for chitin degraders to obtain isolates that were then screened for their ability to hydrolyze the fluorogenic chitinase substrate analogs methylumbelliferyl-diacetylchitobioside (MUF-DC) and methylumbelliferyl-triacetylchitotrioside (MUF-TC) and for their ability to hydrolyze colloidal crab shell chitin. Isolates were probed for chitinase genes using published primer sets (Cottrell et al. 2000, LeCleir et al. 2004) and categorized phylogenetically based on their 16S rRNA gene sequences.

\section{MATERIALS AND METHODS}

MUF hydrolysis in Mono Lake samples. Chitinase activity was assayed in water samples from 5, 15, 20 and $35 \mathrm{~m}$; and in oxic and anoxic sediments collected in February, March, April, May, and June 2002. Mono Lake had been meromictic for $7 \mathrm{yr}$ at the time of sampling. Physiochemical conditions in the lake and watercolumn profiles of physicochemical variables for these sampling dates are reported in Hollibaugh et al. (2005). Water samples were collected at Stn 6 (37 $57.822^{\prime} \mathrm{N}$, $119^{\circ} 01.305^{\prime} \mathrm{W}$ ) from discrete depths using a Niskin sampler. Gas-tight bottles were filled from the Niskin sampler leaving no head space and taking care to prevent oxygenation of the sample, then stored in the dark, on ice or at $4^{\circ} \mathrm{C}$ until assayed (within $4 \mathrm{~h}$ of sample collection). We used the fluorogenic chitin analogue MUF-DC (Sigma) for routine measurements in Mono Lake samples. Although this substrate may be hydro- lyzed by other enzymes (for example lysozyme; Vollan et al. 1999), we assume that it represents chitinolytic activity in our samples. Triplicate MUF-DC hydrolysis assays were performed in $15 \mathrm{ml}$ centrifuge tubes with $4.5 \mathrm{ml}$ of Mono Lake water and $0.5 \mathrm{ml}$ of $0.1 \mathrm{mM} \mathrm{MUF-}$ DC (initially dissolved in dimethyl formamide to a concentration of $5 \mathrm{mM}$ and then diluted in autoclaved and filter-sterilized Mono Lake water). Samples were incubated at 4 and $20^{\circ} \mathrm{C}$ in order to negate differences in chitinolytic activity resulting from different environmental temperatures at the time of sample collection.

Sediment was collected from Stn 6 (37 $7^{\circ} 57.822^{\prime} \mathrm{N}$, $119^{\circ} 01.305^{\prime} \mathrm{W}, 39 \mathrm{~m}$ depth), where the overlying water was anoxic, and from a station north of Stn 6 near Paoha Island, where physical characteristics of the sediment were similar to those at Stn 6 (soupy, organicrich mud of similar grain size and porosity), but where the overlying water was oxygenated $\left(\mathrm{O}_{2}\right.$ concentration $>1 \mathrm{mg} \mathrm{l}^{-1}$ as determined with a YSI oxygen meter equipped with a Clark-type electrode, bottom depth from 10 to $15 \mathrm{~m}$ ). Sediment was collected using an Eckman grab, then surficial sediment was skimmed from the undisturbed sediment-water interface of the sample with a plastic spoon, placed in a glass jar with an air-tight cap, and stored on ice until the assays were performed (within $4 \mathrm{~h}$ ). Triplicate sets of tubes containing $2.5 \mathrm{ml}$ of autoclaved and filter-sterilized Mono Lake water and $2.0 \mathrm{ml}$ of sediment were amended with $0.5 \mathrm{ml}$ of $0.1 \mathrm{mM}$ MUF-DC, then incubated at 20 and $4^{\circ} \mathrm{C}$ with shaking (100 rpm) for 3 or $96 \mathrm{~h}$, respectively.

Fluorescence of $0.2 \mathrm{ml}$ of sample in $1.8 \mathrm{ml}$ of carbonate buffer ( $\mathrm{pH}$ 9.7) was measured at $365 \mathrm{~nm}$ excitation and $460 \mathrm{~nm}$ emission using a Hoefer DynaQuant fluorometer. All environmental measurements of MUF-DC hydrolysis were performed in triplicate. MUF-DC hydrolysis was linear for at least $3 \mathrm{~d}$ in pilot experiments with water samples, and comparison of hydrolysis rates in filtered versus whole-water samples indicated that the bulk of the activity (>90\%) was associated with particles (authors' unpubl. data).

Exuvium assemblage. The microbial assemblage associated with brine shrimp and brine fly exuvia was examined using a sample collected in November 2004 immediately following the fall die-off of the Artemia monica population. Exuvia floating on the lake's surface were collected with a plankton net. DNA was extracted and analyzed by PCR/DGGE, and cloning of 16S rRNA genes was as described below. Data from this sample were compared to data obtained from chitin-enrichment experiments.

Enrichment cultures. We prepared 2 replicates of enrichment cultures in $1 \mathrm{l}$ glass bottles using $500 \mathrm{ml}$ of water for each bottle. Water was collected in February 2002 from $5 \mathrm{~m}$ (aerobic) or $35 \mathrm{~m}$ (anaerobic) at Stn 6 . This experiment was performed in February because 
there are no brine shrimp in the water column at this time of year, thereby eliminating Artemia monica chitin from control samples. Most of the sample $(450 \mathrm{ml})$ was passed through ashed GF/F filters (Whatman). The filtrate was then mixed with the remaining $50 \mathrm{ml}$ of whole, unfiltered Mono Lake water. Experimental treatments were amended with $0.5 \mathrm{~g} \mathrm{l}^{-1}$ autoclaved crab shell chitin (Sigma), while controls received no chitin. Bottles were wrapped in aluminum foil and incubated at in situ temperatures $\left(4^{\circ} \mathrm{C}\right)$ in the dark. The anaerobic samples were manipulated in a Coy anaerobic chamber (Grass Lake).

Following a 4 wk incubation, water was filtered through a $0.22 \mu \mathrm{m}$ Sterivex filter cartridge until the filter clogged ( $250 \mathrm{ml}$ of sample) to collect bacterial cells. The particulate chitin in experimental treatments was not removed prior to filtration to prevent the exclusion of bacteria attached to chitin particles. Sample water was expelled from the Sterivex cartridges, $1.8 \mathrm{ml}$ of lysis buffer (50 mM Tris [pH 8.3], $40 \mathrm{mM}$ EDTA, and $0.75 \mathrm{M}$ sucrose) was added, and then the cartridges were stored at $-80^{\circ} \mathrm{C}$ until processed.

Enumeration. The abundance of bacteria in all treatments of the chitin-enrichment experiment was determined at the beginning and end of the incubation. Samples for enumeration were preserved with $2 \%$ (final concentration) filtered formalin. Bacteria were enumerated by epifluorescence microscopy using 4', 6diamidino-2-phenylindole (DAPI) following a protocol modified slightly from that of Porter \& Feig (1980). Sample $(0.75 \mathrm{ml})$, DAPI solution $(0.75 \mathrm{ml}$ of $0.003 \%$ $\mathrm{w} / \mathrm{v})$, and filter-sterilized, $10 \%$ acetic acid $(0.1 \mathrm{ml}$, we have found that this enhances staining of these samples) were combined and filtered, after 7 min of incubation, onto black, $0.2 \mu \mathrm{m}$ pore size membrane filters (Osmonics), then counted using a Leica DMRXA microscope equipped with epifluorescence optics. At least 10 fields and 300 cells were counted per slide.

DNA extraction, purification, and PCR/DGGE. DNA was extracted from Sterivex cartridges as described previously (Ferrari \& Hollibaugh 1999). Briefly, $40 \mu \mathrm{l}$ of lysozyme $\left(50 \mathrm{mg} \mathrm{m}^{-1}\right)$ was added to each cartridge, and the cartridges were incubated for $60 \mathrm{~min}$ at $37^{\circ} \mathrm{C}$. Then, $50 \mu \mathrm{l}$ of Proteinase $\mathrm{K}\left(20 \mathrm{mg} \mathrm{ml}^{-1}\right)$ and $100 \mu \mathrm{l}$ of a $20 \%(\mathrm{w} / \mathrm{v})$ solution of sodium dodecyl sulfate were added to each cartridge, and the cartridges were incubated at $55^{\circ} \mathrm{C}$ for $2 \mathrm{~h}$. DNA was purified from $800 \mu \mathrm{l}$ of the lysate by sequential extraction with $800 \mu \mathrm{l}$ of phenol/chloroform/isoamyl alcohol (25:24:1), chloroform/isoamyl alcohol (24:1), and, finally, n-butanol. The aqueous phase was added to a Centricon-100 concentrator (Amicon), mixed with $500 \mu \mathrm{l}$ of TE buffer (10 mM Tris and 1 mM EDTA, pH 8.0), and centrifuged at $1000 \times g$ for $10 \mathrm{~min}$. Next, $500 \mu \mathrm{l}$ of TE was added to the Centricon-100 concentrator, and the mixture was centrifuged for another $10 \mathrm{~min}$.
PCR, for DGGE analysis, was performed using the GC-clamped 340-356F and fluorescein-labeled 517533R primer set (Bano \& Hollibaugh 2000). PCR conditions were similar to those used by Ferrari \& Hollibaugh (1999). PCR products were quantified by the Hoechst dye assay (Paul \& Myers 1982). DGGE was performed on a $6.5 \%$ polyacrylamide gel with a 45 to $65 \%$ denaturing gradient using a CBS Scientific DGGE apparatus. Gels were loaded with $400 \mathrm{ng}$ of PCR product per lane, then electrophoresed at $75 \mathrm{~V}$ $\left(3.75 \mathrm{~V} \mathrm{~cm}^{-1}\right)$ for $15 \mathrm{~h}$ in $1 \times$ TAE buffer $(40 \mathrm{mM}$ Tris, $20 \mathrm{mM}$ sodium acetate, $1 \mathrm{mM}$ EDTA [pH adjusted to 7.4 with acetic acid]) at a constant temperature of $60^{\circ} \mathrm{C}$. PCR products in the DGGE gels were visualized using an FMBIO II gel scanner (Hitachi) set to measure fluorescein fluorescence. Selected bands were excised and sequenced on an ABI 310 genetic analyzer with the 340-356F primer.

Gel analysis. Gel analysis was performed using the Molecular Analyst-Fingerprint Plus software (BioRad, Version 1.12). Phylotypes, defined as bands recognized by the software, were counted for each sample lane. Bands were scored as present or absent at each position. The 20 bands in the 10 samples were ordinated with non-metric multidimensional scaling (MDS), using the ViSta software program (Version 5.6, http://forrest.psych.unc.edu/research/index.html).

The MDS was constrained to a 2-dimensional solution and was run from 1000 randomized starts to avoid local minima. The run with the lowest value of stress among these randomized starts was used for analysis.

Clone libraries. Clone libraries were constructed from PCR amplicons produced using the bacteria primer set 9F and 1492R (Lane 1991, Weisburg et al. 1991). PCR product was verified on an agarose gel, and products of the expected size were extracted using the QiaQuick gel extraction kit (Qiagen) and cloned into Escherichia coli using the TOPO TA cloning kit for sequencing (Invitrogen). We randomly selected 20 clones from each library. Cloned inserts were sequenced at the University of Georgia's Molecular Genetics Instrumentation Facility (MGIF) on an ABI 3700 genetic analyzer (Applied Biosystems) with the 9F primer. Sequences were cut to $800 \mathrm{bp}$ in length and queried against GenBank using BLASTN. Database sequences with highest BLASTN similarity values were imported and compared to cloned sequences using the GAP tool of the Wisconsin package, Version 10.2 (Accelrys).

Culturing and phylogeny of chitinolytic isolates. Chitinolytic bacteria were isolated from water and sediment samples, as well as from chitin-enrichment experiments. Samples $(0.1 \mathrm{ml})$ were spread on chitin thin-layer R2A plates (Suzuki et al. 1997) or on plates containing colloidal chitin prepared from pulverized, 
particulate crab shell chitin (Sigma) as the sole carbon and energy source. All plates were made using artificial Mono Lake water (Blum et al. 1998). Although some colonies showed clearing zones indicating production of soluble chitinase, most did not, so colonies were selected randomly after 2 wk growth at $20^{\circ} \mathrm{C}$. Isolates were re-streaked twice on fresh R2A plates, then on plates containing only chitin as a carbon and energy source, and, finally (if they grew on the chitin-only plate), on another R2A plate. Anaerobes were cultured in a Coy anaerobic chamber.

Cells from purified strains were lysed in ultra-pure water by boiling. The lysate was centrifuged briefly to collect cellular debris at the bottom of the tube, and PCR was performed using the supernatant as template. No further sample manipulations were necessary for successful PCR using the bacteria primer set $9 \mathrm{~F}$ and 1492R. PCR products were cleaned using the Qiaquick PCR cleanup kit (Qiagen) and then sequenced on an ABI 310 genetic analyzer using a BigDye terminator cycle sequencing kit (Applied Biosystems) with the 9F primer. Sequences were queried (BLASTN) against the GenBank database, and closest relative sequences were compared to isolate sequences using the GAP tool of the Wisconsin package, Version 10.2 (Accelrys).

Tests for chitinase. Overnight cultures of all isolates were transferred to 96 well plates containing liquid R2A media and autoclaved, particulate chitin; they were then incubated overnight at $20^{\circ} \mathrm{C}$ to induce chitinolytic activity. The following morning wells were amended with MUF-DC or MUF-TC (10 $\mu \mathrm{M}$ final concentration) and incubated for $24 \mathrm{~h}$. Fluorescence (indicating chitinolytic activity) was detected visually using a UV trans-illuminator (UVP).

Chitin plates were routinely inspected to see if clearing zones were formed around individual colonies that would indicate production of soluble chitinase. We also attempted to amplify chitinase genes from Mono Lake isolates and from enrichment cultures using PCR

Table 1. Summary of methylumbelliferyl-diacetylchitobioside (MUF-DC) hydrolysis rates in Mono Lake on April 14, 2002. Water samples were collected in different depths at Stn 6 . Oxic sediment is sediment overlain by oxygenated water, and anoxic sediment is sediment overlain by anoxic water. Incubations were performed at $4^{\circ} \mathrm{C}$. Activity in water-column

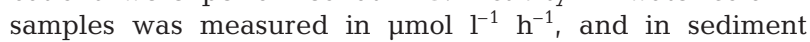
samples in $\mu \mathrm{mol} \mathrm{g}{ }^{-1} \mathrm{~h}^{-1}$

\begin{tabular}{|lc|}
\hline Sample location & Chitinase activity \\
\hline $5 \mathrm{~m}$ & $5.39 \pm 0.85$ \\
$15 \mathrm{~m}$ & $2.94 \pm 0.00$ \\
$25 \mathrm{~m}$ & $3.92 \pm 1.70$ \\
$35 \mathrm{~m}$ & $5.88 \pm 1.47$ \\
Oxic sediment & $0.14 \pm 0.015$ \\
Anoxic sediment & $0.45 \pm 0.022$ \\
\hline
\end{tabular}

primers targeting Family 18, Group I chitinases, as described in LeCleir et al. (2004). We constructed phylogenetic trees of the isolates using 16S rRNA gene sequences; we then selected representative isolates for PCR screening based on tree topology and whether or not they hydrolyzed 1 of the MUF substrates. Representatives of all of the major groups of isolates (all of the $\alpha$ and $\gamma$-Proteobacteria isolates, 23 of the Gram-positive isolates) were screened using these chitinase primers.

\section{RESULTS}

\section{Chitinase activity in Mono Lake}

Chitinolytic activity, as measured by the hydrolysis of MUF-DC, was detected at all depths sampled in the water column and in both sediment samples on all sampling expeditions. Chitinolytic activity in the sediment was always higher than in the water column (Table 1). Water-column rates of MUF-DC hydrolysis were 0.6 to 1.6 and 0.5 to $5.9 \mathrm{nmol} \mathrm{h}^{-1} \mathrm{ml}^{-1}$ for 4 and $20^{\circ} \mathrm{C}$ incubations, respectively. Rates of MUF-DC cleavage in sediment slurries were 3.3 to 81.1 and 137 to $874 \mathrm{nmol} \mathrm{h}^{-1}$ $\mathrm{g}^{-1}$ dry sediment for 4 and $20^{\circ} \mathrm{C}$ incubations, respectively. Reaction $Q_{10}$ values calculated from these data ranged from 1.8 to 4.8 for water-column samples and 3.0 to 9.3 for sediment samples. Chitinolytic activity increased dramatically in May, coincident with the emergence, development, and subsequent molting of brine shrimp Artemia monica nauplii (Fig. 1).

\section{Exuvium assemblage}

We obtained 25 sequences from the Mono Lake exuvium clone library (Table 2). These sequences

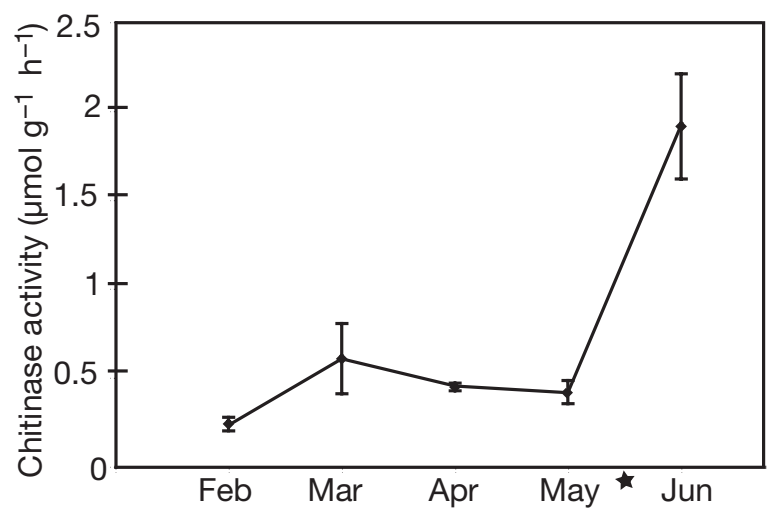

Fig. 1. Artemia monica. Temporal variation of MUF-DC hydrolysis rates in samples of Stn 6 sediments during the development of A. monica population. Star indicates the approximate appearance of adult $A$. monica in Mono Lake 
Table 2. Summary of 16S rDNA sequences obtained from clone libraries. Accession numbers and phylogenetic affiliations are for closest relatives and determined by the BLASTN program of the National Center for Biotechnology Information. Symbols in the column 'Multi source?' indicate ribotypes retrieved from different samples across Tables 2 \& 5. Symbols are placed next to sequences that appeared in multiple enrichments, clone and isolate libraries (and none of the control libraries). Percent identities were determined using the GAP program of the Wisconsin package (CFB: cytophaga-flavobacter-bacteroides)

\begin{tabular}{|c|c|c|c|c|c|}
\hline $\begin{array}{l}\text { Closest } \\
\text { relative }\end{array}$ & $\begin{array}{l}\text { Accession } \\
\text { number }\end{array}$ & $\begin{array}{l}\text { Phylogenetic } \\
\text { affiliation }\end{array}$ & $\begin{array}{c}\text { Multi } \\
\text { source? }\end{array}$ & $\begin{array}{l}\text { Number of } \\
\text { sequences }\end{array}$ & $\begin{array}{c}\text { Percent } \\
\text { similarity }\end{array}$ \\
\hline \multicolumn{6}{|l|}{$5 \mathrm{~m}$, Chitin-enrichment 1 (20 clones) } \\
\hline Gamma-Proteobacterium N10 & AF250323 & $\gamma$-Proteobacteria & - & 9 & $97.5-97.9$ \\
\hline Nitrumincola lacisaponis & AY567473 & $\gamma$-Proteobacteria & $=$ & 1 & 89 \\
\hline Microbulbifer sp. Th/B/38 & AY224196 & $\gamma$-Proteobacteria & TM & 4 & $91.9-92.1$ \\
\hline Unidentified Proteobacterium & AB015518 & $\varepsilon$-Proteobacteria & & 1 & 90 \\
\hline Caulobacter sp. & AJ227811 & $\alpha$-Proteobacteria & & 1 & 95 \\
\hline Lake Nakuru isolate $52 \mathrm{~N} 3$ & X92134 & $\gamma$-Proteobacteria & & 1 & 99 \\
\hline Paracoccus sp. MBIC4036 & AB025192 & $\alpha$-Proteobacteria & $\square$ & 1 & 96 \\
\hline Gamma-Proteobacterium EHK-1 & AF228694 & $\gamma$-Proteobacteria & & 1 & 92 \\
\hline Arhodomonas sp. EL-201 & AJ315984 & $\gamma$-Proteobacteria & $\bullet$ & 1 & 92 \\
\hline \multicolumn{6}{|l|}{$5 \mathrm{~m}$, Chitin-enrichment 2 (20 clones) } \\
\hline Rhodobaca bogoriensis str. LBB2 & AF384205 & $\alpha$-Proteobacteria & $\Delta$ & 9 & $96.3-98.9$ \\
\hline Microbulbifer sp. Th/B/38 & AY224196 & $\gamma$-Proteobacteria & TM & 1 & 91 \\
\hline Bacteroidetes bacterium GMDsbC7 & AY162093 & Bacteroidetes & & 2 & $85.5-86$ \\
\hline Unidentified Proteobacterium & AB015518 & $\varepsilon$-Proteobacteria & & 6 & $88.3-89.3$ \\
\hline Psychroflexus tropicus & AF513434 & Flavobacteria & ] & 1 & 92 \\
\hline Alcanivorax sp. OM-2 & AB053128 & $\gamma$-Proteobacteria & & 1 & 97 \\
\hline \multicolumn{6}{|l|}{$35 \mathrm{~m}$, Chitin-enrichment (20 clones) } \\
\hline Thiomicrospira sp. JB-A1F & AF013976 & $\gamma$-Proteobacteria & & 2 & $97.7-97.8$ \\
\hline Nitrumincola lacisaponis & AY567473 & $\gamma$-Proteobacteria & $=$ & $\overline{7}$ & $93.1-99.2$ \\
\hline Uncultured bacterium SB-83-CS & AJ319865 & Bacteroidetes & & 3 & $85.2-88.4$ \\
\hline Hailaer soda lake bacterium Z4 & AF275713 & $\gamma$-Proteobacteria & & 1 & 94 \\
\hline Gamma-Proteobacterium ML-173 & AF140006 & $\gamma$-Proteobacteria & & 1 & 94 \\
\hline Gamma-Proteobacterium N10 & AF250323 & $\gamma$-Proteobacteria & - & 1 & 94 \\
\hline Alkalliphilus auruminator & AB037677 & Clostridia & & 1 & 89 \\
\hline Thialkalimicrobium sibericum & AF126549 & $\gamma$-Proteobacteria & & 2 & $90.6-91.1$ \\
\hline Idiomarina fontislapidosi & AY526861 & $\gamma$-Proteobacteria & & 1 & 92 \\
\hline Crater Lake isolate $11 \mathrm{C} 1$ & X92129 & $\gamma$-Proteobacteria & & 1 & 95 \\
\hline \multicolumn{6}{|l|}{$5 \mathrm{~m}$, Control (20 clones) } \\
\hline Lewinella nigricans & AF039294 & Sphingobacteria & & 3 & $83.0-83.5$ \\
\hline Unidentified actinobacterium d13 & AJ292034 & Actinobacteridae & & 1 & 94 \\
\hline Chloroplast Picocystis salinarum & AF125173 & Chlorophyta & & 7 & $97.2-97.8$ \\
\hline Uncultured bacterium SB-83-CS & AJ319865 & Bacteroidetes & & 3 & $87.8-88.6$ \\
\hline Legionella adelaidensis & Z49716 & $\gamma$-Proteobacteria & & 2 & $87.4-88.4$ \\
\hline Sulfur-oxidizing bacterium OAII2 & AF170423 & $\gamma$-Proteobacteria & & 1 & 85 \\
\hline Lake Nakuru isolate 19N1 & X92149 & $\gamma$-Proteobacteria & & 1 & 98 \\
\hline Uncultured bacterium gene & AB062814 & Verrucomicrobia & & 1 & 86 \\
\hline Pirellula sp. & X81940 & Planctomycetacia & & 1 & 94 \\
\hline \multicolumn{6}{|l|}{$35 \mathrm{~m}$, Control (19 clones) } \\
\hline Thiomicrospira sp. JB-A1F & AF013976 & $\gamma$-Proteobacteria & & 4 & $81.3-97.8$ \\
\hline Uncultured bacterium SB-83-CS & AJ319865 & Bacteroidetes & & 7 & $88.4-88.6$ \\
\hline Chloroplast Picocystis salinarum & AF125173 & Chlorophyta & & 2 & 98 \\
\hline Bacteroidetes bacterium GMDJE10E6 & AY162091 & Bacteroidetes & & 2 & $89.3-90.8$ \\
\hline Unidentified actinobacterium d13 & AJ292034 & Actinobacteridae & & $\overline{1}$ & 95 \\
\hline Brumimicrobium glaciale & AF521195 & Flavobacteria & & 1 & 90 \\
\hline Firmicutes str. ikaite c10 & AJ431334 & Firmicutes & & 2 & $93-95.7$ \\
\hline \multicolumn{6}{|l|}{ Exuvium sample (25 clones) } \\
\hline Arhodomonas sp. EL-201 & AJ315984 & $\gamma$-Proteobacteria & • & 1 & 96 \\
\hline Uncultured bacterium SBR1071 & AF268996 & Candidate division TM7 & & 1 & \\
\hline Rhodobaca bogoriensis & AF384205 & $\alpha$-Proteobacteria & $\Delta$ & 6 & 96 \\
\hline Paracoccus sp. MBIC4019 & AB025190 & $\alpha$-Proteobacteria & $\square$ & 1 & 96 \\
\hline Bacterium str. 77003 & AF227847 & Gram-positive & & 1 & 98 \\
\hline Triticum aestivum (L.) partial chloroplast & AJ239003 & Streptophyta & & 1 & 96 \\
\hline Vibrio metschnikovii (CIP 69.14T) & X74711 & $\gamma$-Proteobacteria & (C) & 1 & 98 \\
\hline Gamma-Proteobacterium M12-26A & AY730246 & $\gamma$-Proteobacteria & & 1 & 99 \\
\hline Gamma-Proteobacterium HTB021 & AB010859 & $\gamma$-Proteobacteria & & 1 & 93 \\
\hline Plesiocystis pacifica & AB083432 & $\delta$-Proteobacteria & & 1 & 90 \\
\hline Chlorella mirabilis & X65100 & Chlorophyta & & 1 & 93 \\
\hline Halomonas sp. 18bAG & AJ640133 & $\gamma$-Proteobacteria & & 1 & 98 \\
\hline Roseobacter sp. TM1038 & AF384205 & $\alpha$-Proteobacteria & & 1 & 97 \\
\hline Vibrio sp. M12-2C & AY730244 & $\gamma$-Proteobacteria & & 1 & 99 \\
\hline Natronohydrobacter thiooxidans & AJ132383 & $\alpha$-Proteobacteria & & 3 & 97 \\
\hline Psychroflexus tropicus & AF513434 & CFB & ] & 1 & 92 \\
\hline Bacteroidetes bacterium MO54 & AY553122 & CFB & & 1 & 89 \\
\hline Vibrio metschnikovii (NCTC 11170) & $\mathrm{X} 74712$ & $\gamma$-Proteobacteria & (1) & 1 & 98 \\
\hline
\end{tabular}


were from a variety of bacterial groups, including cytophaga-flavobacter-bacteria (CFB), $\alpha-, \delta$ - and $\gamma-$ Proteobacteria. Several sequences were obtained from both the exuvium sample and from chitin enrichments. These sequences were most closely related to Paracoccus sp. MBIC4036 (AB025192), Arhodomonas sp. EL-201 (AJ315984), and Psychroflexus tropicus (AF513434). Bacterial assemblages from the exuvium sample, chitin enrichments, and controls were compared by PCR/ DGGE of 16S rRNA genes. Examination of the gel revealed 5 to 7 bands in the exuvium sample that had the same mobility as bands from chitin enrichments (data not shown). Sequences similar to Vibrio metschnikovii (X74711, X74712) were found in the exuvium clone library and appeared in our isolate collection.

\section{Enrichment experiments}

Bacterial abundance in the aerobic incubations was significantly higher in chitin enrichments compared to initial and control treatments (Table 3); this was not the case for anaerobic incubations, where differences between control and enrichment treatments were not significant. DGGE banding patterns revealed distinct differences between the microbial assemblages in initial, chitin-amended, and control samples (Fig. 2). Sequences obtained from dominant bands from the different treatments confirmed these differences (Table 4 ). With the exception of the $5 \mathrm{~m}$ chitin enrichment, community profiles of duplicate treatments were similar. The richness of the assemblages of Bacteria in all treatments appeared to be relatively low, with no more than 10 distinct bands present in any treatment (Fig. 2).

Five clone libraries were constructed from 16S rRNA genes amplified from each of the 4 treatments of the chitin-enrichment experiment. Clone libraries were generated for both of the $5 \mathrm{~m}$ chitin-enrichment bottles because of the obvious differences in the DGGE community profiles (Fig. 2). Of 20 clones randomly selected for sequencing from each of the libraries, 1 sequencing re-

Table 3. DAPI bacterial counts for initial and final samples from chitin-amended and control treatments of the chitinenrichment experiment. At least 10 fields and 300 cells were counted per slide

\begin{tabular}{|lc|}
\hline Treatment & No. cells $\mathrm{ml}^{-1}\left(\times 10^{6}\right)$ \\
\hline $5 \mathrm{~m}\left(\mathrm{~T}_{\text {initial }}\right)$ & $4.30 \pm 2.16$ \\
$5 \mathrm{~m}$, chitin-amended $\left(\mathrm{T}_{\text {final }}\right)$ & $21.62 \pm 4.59$ \\
$5 \mathrm{~m}$, control $\left(\mathrm{T}_{\text {final }}\right)$ & $11.18 \pm 2.59$ \\
$35 \mathrm{~m},\left(\mathrm{~T}_{\text {initial }}\right)$ & $3.28 \pm 2.27$ \\
$35 \mathrm{~m}$, chitin-amended $\left(\mathrm{T}_{\text {final }}\right)$ & $16.39 \pm 2.27$ \\
$35 \mathrm{~m}$, control $\left(\mathrm{T}_{\text {final }}\right)$ & $15.46 \pm 4.04$ \\
\hline
\end{tabular}

action failed, resulting in 19 sequences from the $35 \mathrm{~m}$ control library. The sequences obtained were most closely affiliated with Clostridia, $\alpha$ - and $\gamma$-Proteobacteria, Bacteroidetes, Sphingobacter, Chlorophyta, and Planctomycetaceae (Table 2). Similarities to GenBank sequences ranged between 81.3 and $98.9 \%$ (Table 2). Four sequences were retrieved exclusively from chitinamended treatments, suggesting that they are from chitinolytic organisms. The following 4 sequences were most closely affiliated with Proteobacteria sequences: $\gamma$-Proteobacterium N10 (AF250323), $\gamma$-Proteobacteria strain 4CA (Nitrumincola lacisponis, AY567473), an unidentified Proteobacterium (Strain BD1-5, AB015518) and Microbulbifer (Strain Th/B/38, AY224196). Cloned sequences with greatest similarity to Strain $4 \mathrm{CA}$ and Strain N10 were found in chitin-amended samples incubated under aerobic and anaerobic conditions.

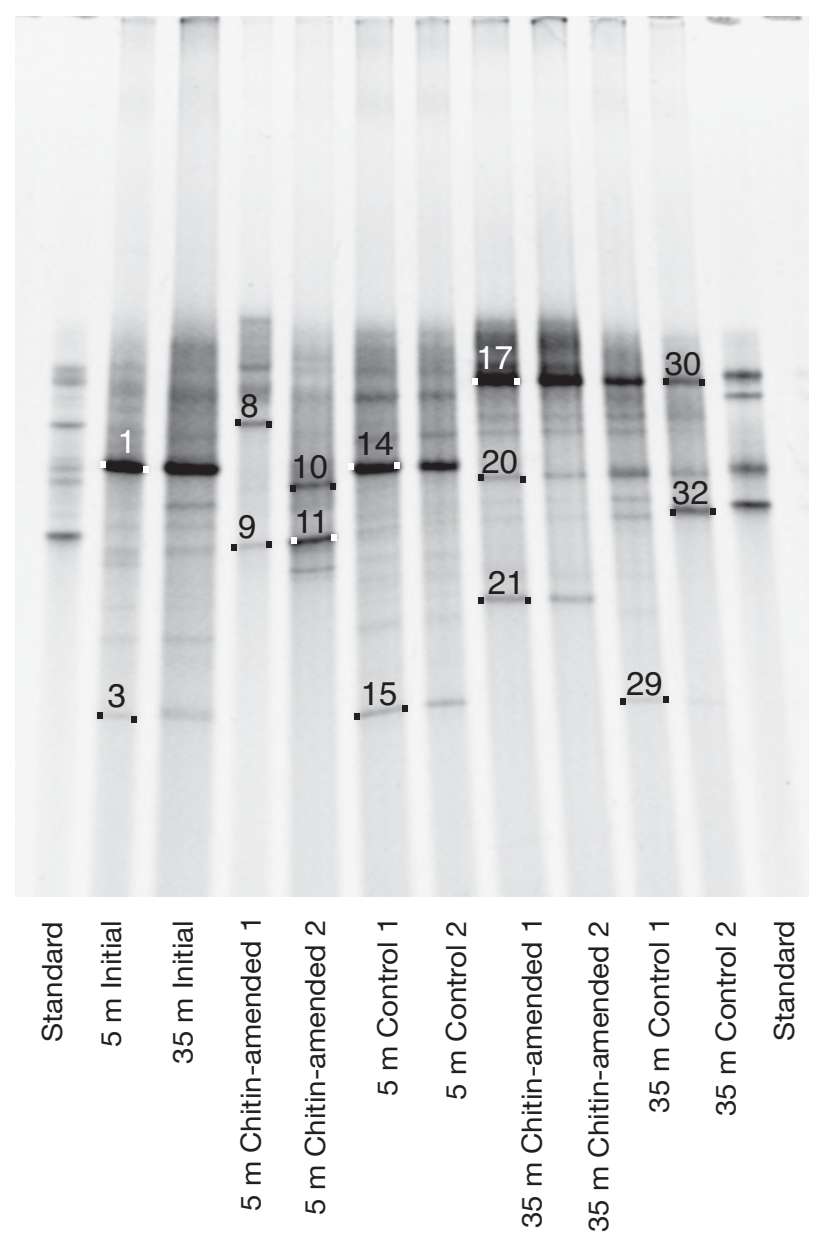

Fig. 2. Image of a denaturing gradient gel electrophoresis (DGGE) gel containing 16S rRNA gene fragments amplified from initial, chitin-amended and control treatments. Phylogeny of numbered bands is shown in Table 4 (1, 2: duplicate treatments) 
Table 4. Phylogeny of dominant band sequences excised from the gel shown in Fig. 2

\begin{tabular}{|ccc|}
\hline Band no. & Treatment & Closest relative \\
\hline 1 & $5 \mathrm{~m}\left(\mathrm{~T}_{\text {initial }}\right)$ & Chloroplast Picocystis salinarum \\
3 & $35 \mathrm{~m}\left(\mathrm{~T}_{\text {initial }}\right)$ & Bacterium Chibacore 1500 \\
8 & $5 \mathrm{~m}$, chitin-amended $\left(\mathrm{T}_{\text {final }}\right)$ & Alkalimonas amylolytica \\
9 & $5 \mathrm{~m}$, chitin-amended $\left(\mathrm{T}_{\text {final }}\right)$ & Rhodobaca bogoriensis strain LBB2 \\
10 & $5 \mathrm{~m}$, chitin-amended $\left(\mathrm{T}_{\text {final }}\right)$ & Synechococcus sp. MW97C4 \\
11 & $5 \mathrm{~m}$, chitin-amended $\left(\mathrm{T}_{\text {final }}\right)$ & Rhodobaca bogoriensis strain LBB2 \\
14 & $5 \mathrm{~m}$, control $\left(\mathrm{T}_{\text {final }}\right)$ & Stenotrophomonas maltophilia \\
15 & $5 \mathrm{~m}$, control $\left(\mathrm{T}_{\text {final }}\right)$ & Bacterium Chibacore 1500 \\
17 & $35 \mathrm{~m}$, chitin-amended $\left(\mathrm{T}_{\text {final }}\right)$ & Nitrumincola lacisaponis \\
20 & $35 \mathrm{~m}$, chitin-amended $\left(\mathrm{T}_{\text {final }}\right)$ & Hymenobacter sp. 29F \\
21 & $35 \mathrm{~m}$, chitin-amended $\left(\mathrm{T}_{\text {final }}\right)$ & Clostridium litorale \\
29 & $35 \mathrm{~m}$, control $\left(\mathrm{T}_{\text {final }}\right)$ & Bacterium Chibacore 1500 \\
30 & $35 \mathrm{~m}$, control $\left(\mathrm{T}_{\text {final }}\right)$ & Proteobacterium Dex60-82 \\
32 & $35 \mathrm{~m}$, control $\left(\mathrm{T}_{\text {final }}\right)$ & Thiomicrospira sp. \\
& & \\
\hline
\end{tabular}

\section{Isolates}

A total of 80 isolates were purified, screened for MUF-DC and MUF-TC activity, and sequenced; 46 isolates were capable of hydrolyzing MUF-DC, 49 isolates were capable of hydrolyzing MUF$\mathrm{TC}$, and 43 isolates were capable of hydrolyzing both MUF-DC and MUF-TC under the conditions tested (Table 5). With the exception of 4 Vibrio isolates, none of our isolates caused clearings in the colloidal chitin agar that would indicate production of soluble chitinase. With the exception of the same Vibrio isolates, we were unable to amplify chitinase genes from any of the isolates using Family 18, Group 1 chitinase primers.

Table 5. Phylogenetic affiliation of isolates and their ability to hydrolyze chitin analogs. Accession numbers and phylogenetic affiliations are for closest matches (at least $363 \mathrm{bp}$ of informative sequence information) and determined by the BLASTN program of the National Center for Biotechnology Information. Symbols in the column headed 'Multi source?' indicate ribotypes retrieved from different samples across Tables 2 \& 5. 'Number of isolates' indicates the number of isolates that had the same closest relative; the range of similarity values for the 16S rRNA gene sequences for these isolates is given in the column headed 'Percent similarity.' The plus and minus symbols indicate that a substrate was or was not, respectively, hydrolyzed by the isolate, and the numbers in parentheses indicate the number of isolates of that ribotype that were active towards the substrate (MUF-DC, MUF-TC: methylumbelliferyl-diacetylchitobioside and -triacetylchitobioside, respectively)

\begin{tabular}{|c|c|c|c|c|c|c|c|}
\hline $\begin{array}{l}\text { Closest } \\
\text { relative }\end{array}$ & $\begin{array}{l}\text { Accession } \\
\text { number }\end{array}$ & $\begin{array}{l}\text { Phylogenetic } \\
\text { affiliation }\end{array}$ & $\begin{array}{c}\text { Multi } \\
\text { source? }\end{array}$ & $\begin{array}{c}\text { Number of } \\
\text { isolates }\end{array}$ & $\begin{array}{l}\text { Percent } \\
\text { similarity }\end{array}$ & MUF-DC & MUF-TC \\
\hline \multicolumn{8}{|l|}{ Aerobic isolates } \\
\hline Arctic sea ice bacterium ARK10255 & AF468429 & Flavobacteria & & 1 & 92.8 & - & - \\
\hline Halomonas sp. A-07 & AY347310 & $\gamma$-Proteobacteria & & 4 & $96.4-99.7$ & $(2)+$ & $(2)+$ \\
\hline Rhodobaca bogoriensis str. LBB2 & AF384205 & $\alpha$-Proteobacteria & $\Delta$ & 3 & $95.3-98.9$ & $(2)+$ & $(1)+$ \\
\hline Lake Elmenteita isolate WE1 & X92164 & Bacillales & & 1 & 98.2 & + & - \\
\hline Halomonas sp. EF11 & AY332559 & $\gamma$-Proteobacteria & & 1 & 95.4 & + & + \\
\hline Bacillus sp. ZBAW6 & AY453415 & Bacillales & & 1 & 95 & + & + \\
\hline Bacillus sp. GSP75 & AY553091 & Bacillales & & 1 & 96.9 & + & + \\
\hline Gamma-Proteobacterium N10 & AF250323 & $\gamma$-Proteobacteria & - & 1 & 95.0 & + & + \\
\hline Bacillus sp. T41 & AB111934 & Bacillales & & 1 & 97.4 & + & + \\
\hline Azospirillum sp. TTI & AF170353 & $\alpha$-Proteobacteria & & 1 & 86.4 & - & - \\
\hline Alpha Proteobacterium ML-168a & AF140003 & $\alpha$-Proteobacteria & & 4 & $97.6-98.1$ & - & $(4)+$ \\
\hline Vibrio metschnikovii (NCTC 11170) & $\mathrm{X} 74712$ & $\gamma$-Proteobacteria & $®$ & 2 & 98 & $(2)+$ & $(2)+$ \\
\hline Vibrio metschnikovii (CIP 69.14T) & $\mathrm{x} 74711$ & $\gamma$-Proteobacteria & (C) & 1 & 98 & + & + \\
\hline \multicolumn{8}{|l|}{ Anaerobic isolates } \\
\hline Paraliobacillus ryukyuensis & AB087828 & Bacillales & & 8 & $92.4-94.3$ & $(4)+$ & $(4)+$ \\
\hline Amphibacillus tropicus & AF418602 & Bacillales & & 26 & $86.1-94.3$ & $(25)+$ & $(25)+$ \\
\hline Natronincola histidinovorans & Y16716 & Clostridia & & 2 & $90.8-92.7$ & - & $(1)+$ \\
\hline Halomonas sp. LBB1 & AY334093 & $\gamma$-Proteobacteria & & 1 & 93.8 & - & - \\
\hline Halomonas sp. A-07 & AY347310 & $\gamma$-Proteobacteria & & 1 & 99.8 & - & + \\
\hline Hailaer soda lake bacterium F24 & AF275702 & Lactobacillales & & 2 & $98.8-99.2$ & $(2)+$ & $(2)+$ \\
\hline Marinobacter flavimaris str. SW-145 & AY517632 & $\gamma$-Proteobacteria & & 1 & 90.8 & + & + \\
\hline Bacillus sp. ZBAW6 & AY453415 & Bacillales & & 1 & 95.1 & + & - \\
\hline Hailaer soda lake bacterium F10 & AF275698 & Bacillales & & 1 & 97.4 & - & - \\
\hline Bacillus selenitireducens & AF064704 & Bacillales & & 8 & $98.3-99.8$ & - & - \\
\hline Hailaer soda lake bacterium T2 & AF275708 & Bacillales & & 4 & $97.2-99.5$ & - & - \\
\hline Uncultured Fusobacteria bacterium & AJ575990 & Fusobacteria & & 1 & 89.5 & - & - \\
\hline Vibrio metschnikovii (CIP 69.14T) & $\mathrm{X} 74711$ & $\gamma$-Proteobacteria & ( & 1 & 98.4 & + & + \\
\hline Tindallia californiensis & AF373919 & Clostridia & & 1 & 96.4 & - & - \\
\hline
\end{tabular}




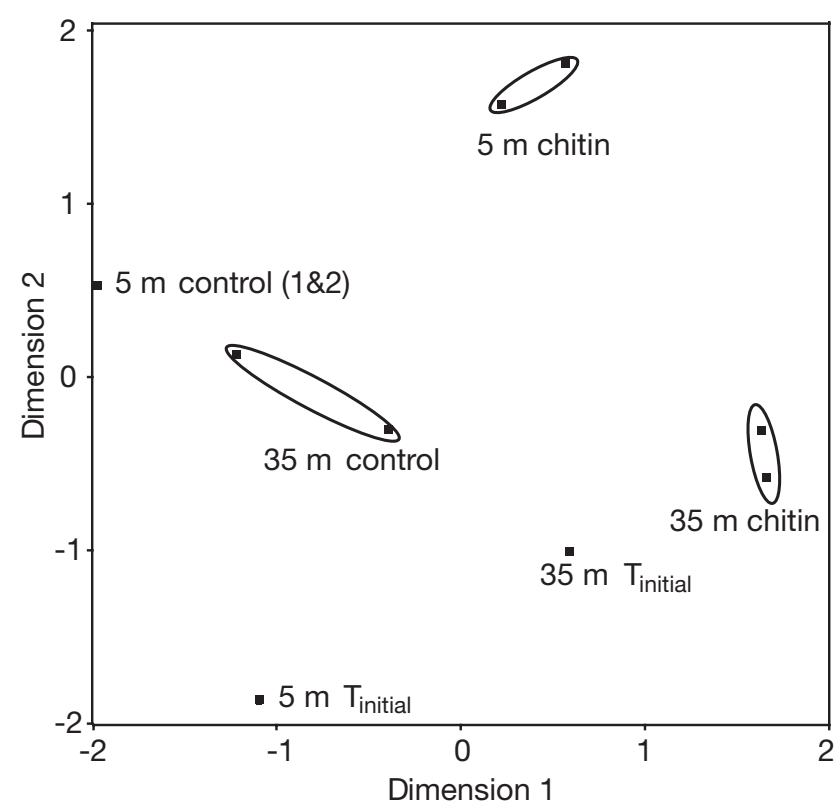

Fig. 3. Plot of sample scores from non-metric multidimensional scaling analysis of DGGE banding patterns from initial, chitin-amended, and control treatments. Final stress was 0.1062. Treatments most similar to one another appear closer on the figure

Sequences of 16S rRNA genes obtained from isolates in this study ranged from 363 to $767 \mathrm{bp}$ in length. Phylogenetic affiliation of isolates included $\alpha$ - and $\gamma$ Proteobacteria, Bacillus, Clostridia, Lactobacillus, and Fusobacteria. These sequences were between 86.1 and $99.8 \%$ similar to $16 \mathrm{~S}$ rRNA gene sequences in GenBank. The majority ( $73 \%$ ) of the isolates were members of the Gram-positive group, and $70 \%$ of the Gram-positive isolates were capable of hydrolyzing at least 1 of the model substrates (Table 5).

\section{DISCUSSION}

In agreement with studies from other environments, chitinase activity is higher in sediments than in the water column of Mono Lake (Herwig et al. 1988, Smucker \& Kim 1991). Our data indicate that sediment chitinolytic activity responds to the emergence and development of the Artemia monica population in the water column (Fig. 1). The May to June increase in chitinolytic activity may be due to an increase in the abundance of chitinolytic microbes or to up-regulation of chitinolytic protein expression in response to greater substrate availability. Molting arthropods also produce chitinases (Merzendorfer \& Zimoch 2003), so chitinolytic activity, especially in the water column, may increase as the number of molting $A$. monica increases.
The ability of isolates to hydrolyze MUF substrates conveys information about the types of chitinases produced by these bacteria. It is assumed that bacteria capable of hydrolyzing MUF-DC produce exo-chitinases and those hydrolyzing MUF-TC produce endochitinases (Cottrell et al. 1999). Microbes hydrolyzing both substrates potentially produce both endo- and exo-chitinases. Although some isolates hydrolyzed only 1 of the chitin analogues, over half of them could hydrolyze both (Table 5). From our results it appears that endo- and exo-chitinolytic activity is evenly distributed in Mono Lake isolates. The production of multiple chitinases by a single organism is well documented (Svitil et al. 1997), and is not surprising given the complex structure of chitin (Gooday 1990, Svitil et al. 1997).

The difficulty we encountered in amplifying chitinases from our chitinolytic isolates is not uncommon (Cottrell et al. 2000). The negative results are likely due to the high variability found within chitinase gene sequences (Svitil \& Kirchman 1998). It is also possible that MUF substrates are hydrolyzed by completely different enzymes from those used in chitin degradation. For example, lysozyme is capable of hydrolyzing MUF analogues (Vollan et al. 1999), and may have been responsible for some of the activity we were measuring with them, hence the lack of chitinase gene products in our PCR. Since our isolates were capable of growth on chitin as the sole $\mathrm{C}$ and energy source, it seems unlikely that they lack the ability to hydrolyze chitin.

Bacterial abundances increased significantly in aerobic chitin enrichments compared to initial and control treatments; however, bacterial abundances did not increase in anaerobic incubations (Table 3). The addition of nitrogen-rich chitin may have stimulated growth in the surface samples by eliminating the nitrogen limitation that can be characteristic of Mono Lake surface water. Another possibility is that a lack of suitable electron acceptors in the highly reduced bottom water of Mono Lake limited growth in the anaerobic incubations.

The Mono Lake bacterial community appears to respond strongly to chitin enrichment. We obtained 4 sequences from multiple 16S rDNA clone libraries of chitin-amended samples that were not obtained from any of the control bottles. Additionally, MDS analysis of DGGE banding patterns indicates a strong relationship between the presence of chitin and the composition of the bacterial assemblage (Fig. 3). Our results suggest that chitin production by Artemia monica may influence the seasonal succession of the microbial community in Mono Lake because of the strongly seasonal population dynamics of A. monica (Dana et al. 1990). 
We were able to obtain isolates that grew on chitin plates from a wide variety of phylogenetic groups (Table 5). The amount of phylogenetic overlap, however, between culturable chitinolytic isolates and sequences retrieved from our enrichment cultures is small. Only sequences from Rhodobaca bogoriensis (AF384205) and Gamma-Proteobacterium N10 (AF250323) were common to both the isolates collection and to sequences cloned from enrichment cultures. $16 \mathrm{~S}$ rRNA gene sequences most similar to Vibrio metschnikovii (X74712 and X74711) were found among the isolates and in the Mono Lake exuvium clone library. While there are large differences between the phylogenetic compositions of our isolate collection and our clone libraries, the phylogenetic distribution of bacteria isolated in this study is similar to that in a study by Cottrell et al. (2000). The lack of overlap between isolate and enrichment cultures is likely a result of the difficulties encountered when trying to culture bacteria from the environment. It is likely that the bacteria we isolated on chitin plates represent only the portion of chitinolytic microbes that are easily cultured on plates. Nevertheless, these isolates are chitinolytic and will be useful for future studies of chitinases from Mono Lake and similar environments.

Many of the 16S rRNA gene sequences obtained from the enrichment cultures were quite different from any 16S sequences currently in GenBank, despite the fact that similar studies have investigated chitin degradation in other environments (Cottrell et al. 2000, Metcalfe et al. 2002). The low similarity between database sequences and ribotypes retrieved from exuvium or chitin-amended samples makes inference of the functional capabilities of these organisms virtually impossible. However, the unique association of certain ribotypes with chitin-amended treatments suggests that those organisms are important in, or associated with, chitin degradation in some way. The fact that these 'chitinophilic' sequences are all Proteobacteria is consistent with previous work, because Proteobacteria have been identified as playing an important role in chitin hydrolysis in other environments (Svitil et al. 1997, Keyhani \& Roseman 1999, Cottrell et al. 2000, Howard et al. 2004). In contrast, Gram-positive ribotypes were not dominant in any of our clone libraries, despite the fact that they comprised $73 \%$ of the cultures we isolated on media that selected for chitin-degrading organisms and that the majority of the Gram-positive isolates we cultured were capable of cleaving MUF compounds. While this discrepancy may be due to PCR or DNA extraction biases, we have had no trouble extracting or amplifying DNA from Gram-positive cultures, or from environmental DNA (Humayoun et al. 2003), so it is more likely that the discrepancy results from strong selection during the isolation procedure.
Our results suggest that $\alpha$ - and $\gamma$-Proteobacteria and Gram-positive bacteria are active members of the chitinolytic assemblage in Mono Lake. Members of these lineages were associated with Artemia monica exuvia collected from Mono Lake and in chitin-amended enrichment cultures. Members of these groups have also been isolated on chitin plates and have demonstrated MUF substrate (MUF-DC and MUF-TC) hydrolysis. Our results are in agreement with studies conducted in other environments (Watanabe et al. 1990, 2003, Cottrell et al. 2000, Howard et al. 2004).

Using PCR to retrieve Family 18, Group I chitinase gene sequences from environmental DNA samples collected in Mono Lake has thus far been unsuccessful. Conservation within other groups of bacterial chitinase genes is presently too low for primer development, so we turned to other approaches to gain insight into the chitinolytic microbial community of Mono Lake. Using both culture-dependent and -independent techniques, we have been able to circumvent the difficulties inherent in primer design and PCR analysis of highly variable functional genes to characterize the chitinolytic bacterial assemblage from Mono Lake. These results will help us focus future efforts in order to study chitinolytic microbes in Mono Lake and similar environments.

Acknowledgements. We thank Drs. N. Bano, R. Jellison, and A. Buchan for their help with experimental design, sample collection, and manuscript review. S. Carini and S. Roll were essential members of the sample collection team. This work was supported by NSF MCB 9977886 awarded to J.T.H. and S. B. Joye.

\section{LITERATURE CITED}

Bano N, Hollibaugh JT (2000) Diversity and distribution of DNA sequences with affinity to ammonia-oxidizing bacteria of the beta subdivision of the class Proteobacteria in the Arctic Ocean. Appl Environ Microbiol 66:1960-1969

Blum JS, Bindi AB, Buzzelli J, Stolz JF, Oremland RS (1998) Bacillus arsenicoselenatis, sp. nov., and Bacillus selenitireducens, sp. nov.: two haloalkaliphiles from Mono Lake, California that respire oxyanions of selenium and arsenic. Arch Microbiol 171:19-30

Conte FP, Jellison RS, Starrett GL (1988) Nearshore and pelagic abundances of Artemia monica in Mono Lake, California. Hydrobiologia 158:173-181

Cottrell MT, Moore JA, Kirchman DL (1999) Chitinases from uncultured marine microorganisms. Appl Environ Microbiol 65:2553-2557

Cottrell MT, Wood DN, Yu LY, Kirchman DL (2000) Selected chitinase genes in cultured and uncultured marine bacteria in the alpha- and gamma-subclasses of the proteobacteria. Appl Environ Microbiol 66:1195-1201

Dana GL, Foley CJ, Starrett GL, Perry WM, Melack JM (1988) In situ hatching of Artemia monica cysts in hypersaline Mono Lake, California. Hydrobiologia 158:183-190

Dana GL, Jellison R, Melack JM (1990) Artemia monica cyst production and recruitment in Mono Lake, California, USA. Hydrobiologia 197:233-243 
Ferrari VC, Hollibaugh JT (1999) Distribution of microbial assemblages in the Central Arctic Ocean Basin studied by PCR/DGGE: analysis of a large data set. Hydrobiologia 401:55-68

Gooday GW (1990) The ecology of chitin degradation. Adv Microb Ecol 11:387-430

Henrissat B (1991) A classification of glycosyl hydrolases based on amino-acid-sequence similarities. Biochem J 280:309-316

Herwig RP, Pellerin NB, Irgens RL, Maki JS, Staley JT (1988) Chitinolytic bacteria and chitin mineralization in the marine waters and sediments along the Antarctic Peninsula. FEMS Microbiol Ecol 53:101-111

Hollibaugh JT, Carini S, Gurleyuk H, Jellison R and 5 others (2005) Arsenic speciation in Mono Lake, California: response to seasonal stratifaction and anoxia. Geochim Cosmochim Acta 69:1925-1937

Howard MB, Ekborg NA, Taylor 2nd LE, Weiner RM, Hutcheson SW (2004) Chitinase B of 'Microbulbifer degradans' 2-40 contains two catalytic domains with different chitinolytic activities. J Bacteriol 186:1297-1303

Humayoun SB, Bano N, Hollibaugh JT (2003) Depth distribution of microbial diversity in Mono Lake, a meromictic soda lake in California. Appl Environ Microbiol 69: 1030-1042

Keyhani NO, Roseman S (1999) Physiological aspects of chitin catabolism in marine bacteria. Biochim Biophys Acta 1473: 108-122

Lane DJ (1991) 16S/23S rRNA sequencing. In: Stackebrandt E, Goodfellow M (eds) Nucleic acid techniques in bacterial systematics. Academic Press, Chichester, p 115-175

LeCleir GR, Buchan A, Hollibaugh JT (2004) Chitinase gene sequences retrieved from diverse aquatic habitats reveal environment-specific distributions. Appl Environ Microbiol 70:6977-6983

Lenz PH (1984) Life-history analysis of an Artemia population in a changing environment. J Plankton Res 6:967-983

Merzendorfer H, Zimoch L (2003) Chitin metabolism in insects: structure, function and regulation of chitin synthases and chitinases. J Exp Biol 206:4393-4412

Metcalfe AC, Krsek M, Gooday GW, Prosser JI, Wellington EMH (2002) Molecular analysis of a bacterial chitinolytic community in an upland pasture. Appl Environ Microbiol 68:5042-5050

Muyzer G, de Waal EC, Uitterlinden AG (1993) Profiling of complex microbial populations by denaturing gradient gel electrophoresis analysis of polymerase chain reactionamplified genes coding for 16S rRNA. Appl Environ Microbiol 59:695-700

Editorial responsibility: Jed Fuhrman,

Los Angeles, California, USA
Patten DT, Conte FP, Cooper WE, Dracup J and 7 others (1987) The Mono Basin ecosystem: effects of changing lake level. National Academy Press, Washington, DC

Paul JH, Myers B (1982) Fluorometric determination of DNA in aquatic microorganisms by use of Hoechst-33258. Appl Environ Microbiol 43:1393-1399

Porter KG, Feig YS (1980) The use of DAPI for identifying and counting aquatic microflora. Limnol Oceanogr 25:943-948

Poulicek M, Gaill F, Goffinet G (1998) Chitin biodegradation in marine environments. Nitrogen-containing macromolecules in the bio- and geosphere. ACS Symposium Series 707. American Chemical Society, Washington, DC, p 163-210

Ramaiah N, Hill RT, Chun J, Ravel J, Matte MH, Straube WL, Colwell RR (2000) Use of a chiA probe for detection of chitinase genes in bacteria from the Chesapeake Bay. FEMS Microbiol Ecol 34:63-71

Smucker RA, Kim CK (1991) Chitinase activity in estuarine waters. In: Chrost R (ed) Microbial enzymes in aquatic environments. Springer-Verlag, Heidelberg, p 239-248

Suzuki M, Rappe M, Haimberger Z, Winfield H, Adair N, Strobel J, Giovannoni S (1997) Bacterial diversity among small-subunit rRNA gene clones and cellular isolates from the same seawater sample. Appl Environ Microbiol 63: 983-989

Svitil AL, Kirchman DL (1998) A chitin-binding domain in a marine bacterial chitinase and other microbial chitinases: implications for the ecology and evolution of 1,4-beta-glycanases. Microbiology 144:1299-1308

Svitil AL, Chadhain SMN, Moore JA, Kirchman DL (1997) Chitin degradation proteins produced by the marine bacterium Vibrio harveyi growing on different forms of chitin. Appl Environ Microbiol 63:408-413

Vollan VB, Hough E, Karlsen S (1999) Structural studies on the binding of 4-methylumbelliferone glycosides of chitin to rainbow trout lysozyme. Acta Crystallogr Sect D Biol Crystallogr 55:60-66

Watanabe T, Oyanagi W, Suzuki K, Tanaka H (1990) Chitinase system of Bacillus circulans WL-12 and importance of chitinase A1 in chitin degradation. J Bacteriol 172: 4017-4022

Watanabe T, Ariga Y, Sato U, Toratani T and 5 others (2003) Aromatic residues within the substrate-binding cleft of Bacillus circulans chitinase A1 are essential for hydrolysis of crystalline chitin. Biochem J 376:237-244

Weisburg WG, Barns SM, Pelletier DA, Lane DJ (1991) 16s ribosomal DNA amplification for phylogenetic study. J Bacteriol 173:697-703

Submitted: June 18, 2005; Accepted: December 16, 2005 Proofs received from author(s): February 10, 2006 